\title{
MOLECULAR STUDY OF FMD INFECTED EGYPTIAN BUFFALO CALVES WITH REFERENCE TO ELECTROCARDIOGRAPHY AND CARDIAC BIOMARKERS AS PROGNOSTIC TOOLS
}

\author{
ABDELGHANY HEFNAWY ${ }^{1}$; MAHMOUD A.Y. HELAL ${ }^{1}$; MARAWAN A. MARAWAN ${ }^{1}$; \\ RANIA ABO- SAKAYA ${ }^{1}$ and HALLA E.K. EL BAHGY ${ }^{2}$ \\ ${ }^{1}$ Department of Animal Medicine Faculty of Veterinary Medicine Benha University - Egypt \\ ${ }^{2}$ Department of Hygiene and Veterinary Care, Faculty of Veterinary Medicine Benha University - Egypt
}

Received: 30 September 2018; Accepted: 30 October 2018

\begin{abstract}
A total of 200 Egyptian buffalo calves aging between 9-11 months previously vaccinated with local trivalent oil inactivated vaccine (O, A and SAT-2), in different locations at Menufyia Governorate showing typical clinical signs of FMD were examined for molecular characterization of FMD virus, electrocardiographic picture (ECG) and cardiac biomarkers. The results of serological tests revealed that incidence of non-structural proteins against natural infection with FMDV was $31.5 \%$ in serum samples collected from vaccinated buffalo calves. Moreover, $51.5 \%$ of the samples showed detection of structural proteins against trivalent vaccination. On the other hand, there were no protective antibodies against FMDV in $17 \%$ of the examined samples. ECG of FMD infected calves showed ventricular premature depolarization with flattening of $\mathrm{P}$ - wave and increased QRS duration with decrease in its amplitude compared with healthy calves. In FMD infected buffalo calves, there were significant $(\mathrm{P}<0.01)$ increases in $(\mathrm{cTnI}),(\mathrm{CK}-\mathrm{MB})$, urea, $\mathrm{CL}$ and $\mathrm{K}$ and there was significant $(\mathrm{P}<0.01)$ decrease in $\mathrm{Na}$ levels than that of healthy ones. The identified strains in FMD infected Egyptian buffalo calves were unique and different from the vaccinal and other Egyptian strains as well as they were clustered with Topotype ME-SA. Cardiac enzymes along with ECG can be used as useful prognostic tools in FMD infected Egyptian buffalo calves.
\end{abstract}

Key words: Calves, Cardiac, ECG, FMD

\section{INTRODUCTION}

Foot-and-mouth disease (FMD) is an important livestock disease of cloven-hoofed animals resulting in drastic direct economic impact including high mortality and severe productivity losses, in addition to indirect losses through importation restriction from endemic localities (Arzt et al., 2011). FMD is a contagious disease and highly transmissible, moreover, a limited number of infective particles can initiate host infection. Contaminated animal products, agricultural tools, people, vehicles, and airborne transmission can contribute to the mechanical dissemination of FMD virus with higher incidence in cold seasons than others (Longjam et al., 2011).

Corresponding author: Dr. Mahmoud A.Y. Helal E-mail address: mahmoudatef75@yahoo.com Present address: Department of Animal Medicine Faculty of Veterinary Medicine Benha University - Egypt
FMD is caused by a non-enveloped icosahedral virus of genus Aphthovirus, family Picornaviridae with a single-stranded and positive-sense RNA (Racaniello, 2001). FMD virus has been classified into seven immunologically distinct serotypes (A, C, O, Asia 1, SAT 1, SAT 2, and SAT 3). The viral genome is further subdivided into $\mathrm{P} 1, \mathrm{P} 2$ and $\mathrm{P} 3$ regions. The $\mathrm{P} 1$ region encodes leader proteinase (Lpro) and structural proteins 1A (VP4), 1B (VP2), 1C (VP3), and 1D (VP1). The $\mathrm{P} 2$ region encodes nonstructural proteins $2 \mathrm{~A}, 2 \mathrm{~B}$, and $2 \mathrm{C}$, while $\mathrm{P} 3$ region encodes 3A, 3B (VPg), 3C protease and 3D polymerase (Bergmann et al., 2003; Carrillo et al., 2005; Lim et al., 2005).

According to the geographic distribution, the $\mathrm{O}$ serotype is divided into eleven topotypes: EAST AFRICA 1 to 4 (EA-1 to -4 ), SOUTHEAST ASIA (SEA), EUROPE-SOUTH AMERICA (EURO-SA), INDONESIA-1 and -2 (ISA-1 and -2), CATHAY, MIDDLE EAST-SOUTH ASIA (ME-SA) and WEST AFRICA (WA). Furthermore, a toptype further divides into genetic lineages and sublineages (Knowles et al., 2016; Knowles et al., 2007). 
The epidemiological information of FMD in Egypt revealed that the disease is enzootic in Egypt, and outbreaks have been reported since 1950 (ElBagoury et al., 2015). FMD virus serotypes O, A and SAT2 are the most prevalent and were last isolated during autumn and winter 2016 and spring and summer 2017 at different Egyptian governorates (El-Bagoury et al., 2017).

Serological detection of antibodies directed to some nonstructural protein (NSPs) of FMD virus using ELISA are useful in providing evidence of previous or current infection in the host, irrespective of vaccination status (OIE. 2009). The most reliable single NSP indicator is the poly-protein $3 \mathrm{ABC}$ antibodies which appear to provide conclusive evidence of previous infection, whether or not the animal have also been vaccinated so, the differentiation between infected and vaccinated animals could be detected easily (Laila and Daoud 2004).

The molecular characterization of virus isolate is very important issue for FMD control (DiMarchi et al., 1986). It has been shown that viral protein 1 (VP1) is highly polymorphic and the most variable among the capsid polypeptides and is considered to be the major immunogenic protein, since it contains a linear antigenic site able to induce neutralizing antibodies sufficient to protect animals against the disease (Cottam et al., 2008). Nucleotide sequencing and phylogenetic analysis of the complete or partial genomic region coding for VP1 has been extensively used as a main tool for molecular epidemiological studies, the development of engineering vaccine, the establishment of diagnostic methods to trace the origin and the spread of FMD virus also for typing and subtyping of the virus (Hall 2001; Knowles et al., 2009).

In calves, myocarditis is considered a fatal form of FMD that occurs without developing the characteristic blister lesions noted in adult cattle. Diagnosis of myocardial disease in cattle remains challenging and is based upon physical examination, cardiac auscultation, and the incidence of sudden death in the field. However, there are many biomarkers for myocardial injury, such as creatine kinase myocardial band (CK-MB), lactate dehydrogenase, cardiac Troponins (cTnI) and aspartate aminotransferase (Jaffe et al., 1996). The best cardiac biomarkers for myocardial damage are cardiac troponins, especially (cTnI), because it has nearly absolute myocardial tissue specificity and higher sensitivity than other myocardial enzymes (Weber et al., 2005). However, no more studies have particularly evaluated the contributing factors of heart affections by using electrocardiography (ECG) in FMD infected Egyptian buffalo calves. The aim of this study was focused on the molecular characterization of FMD virus, electrocardiographic picture and evaluation of some cardiac biomarkers in FMD infected Egyptian buffalo calves.

\section{MATERIALS AND METHODS}

\begin{abstract}
Animals:
The procedures of the current study were carried out according to the guidelines of faculty of veterinary medicine, Benha University for using of animals under ethics approval no (BUFVTM0108).
\end{abstract}

A total of 200 Egyptian buffalo calves aging between 9-11 months previously vaccinated with local trivalent oil inactivated vaccine $(\mathrm{O}, \mathrm{A}$ and SAT-2), in different locations at Menufyia Governorate showing typical clinical signs of FMD including fever, salivation, loss of appetite, depression, lameness, blisters or vesicles, erosions and ulcers in the mucosa of the mouth, tongue, lips, gums, pharynx, palate and between the claws were included in this study.

\section{ECG examination}

FMD infected buffalo calves were examined by base apex lead system II was applied as; the right forelimb electrode was placed on the right side of the neck along the jugular groove one third of the way up the neck. The left forelimb electrode was placed on the ventral midline under the apex of the heart. The ground cables were placed on the left and right stifle joints. Alligator clips moisten with alcohol were used (Hiwing 1977). 20 vaccinated healthy buffalo calves were used control.

\section{Samples}

Serum samples were collected during the period between September 2016 and July 2017 for serological and biochemical analysis including urea which was determined spectrophotometrically by using special kits according to the method that described by Patton and Crouch (1977), sodium and potassium were measured according to the method that described by Henry et al. (1974), and chloride was measured according to Kaplan and Pesca (1996). cTnI concentration was measured according to Carrillo et al. (2005), while serum level of CKMB were measured in full automated biochemistry analyzer (Chemray 240. USSR). 20 vaccinated healthy buffalo calves were used control.

Samples of epithelial tissues were collected from tongue and buccal mucosa of 20 infected calves under standard biosafety conditions and were collected in sterilized tube that contained glycerol and phosphate-buffered saline (PBS) 1:1, pH 7.2-7.6 (Mandour et al., 2014) and stored at $-80^{\circ} \mathrm{C}$ until used for molecular detection of FMD antigen by using RT-PCR, sequential and phylogenetic analysis. 


\section{Serological detection of FMD antibodies and serotyping using ELISA.}

Detection of IgG antibodies in calves' serum samples for detection of non-structural proteins was carried out by using FMD virus $3 \mathrm{ABC}$ - trapping ELISA (IZSLER, Biotechnology lab, via A. Bianchi, 9-25124 Brescia, Italy) according to manufacturer's instructions. All sera samples were subjected to indirect sandwich ELISA for serotyping of FMDV antibodies (IZSLER Biotech laboratory, pirbright institute, UK) according to manufacturer's instructions.

\section{Molecular detection of FMD virus VP1 gene by using RT-PCR}

The viral RNA was extracted from epithelial tissues samples by QIAamp®Viral RNA Mini Kit (Qiagen, Hilden, Germany) following the mini spin protocol according to the manufacturer's instructions. $1 \mu \mathrm{l}$ of the obtained RNA was used as the template in a onestep RT-PCR [Ready-To-Go RT-PCR Beads; Amersham)

The primers used were: Forward primer (FMD virus/O/FP): 5' CCTCCTTCAAYTTACGGTG 3' [5] and Reverse universal primer (NK61): 5' GACATGTCCTCCTGCATCTG $3^{\prime}$ to amplify a target amplicon with 283 bp in length. The amplification reaction was carried out using thermalcycler and PCR conditions were adjusted according to Li et al. (2011).

\section{Virus sequencing and phylogenetic analysis}

The obtained RT-PCR products were purified by Qiaquick PCR purification kit (Qiagen) according to the manufacturer's instructions. Sequence analysis was carried out to detect the nucleotide composition of the detected strain for genotypic analysis and it was carried out in both directions using the previously mentioned forward primer and reverse primers by 3730 DNA Analyzer, Applied Biosystems, USA. Big Dye Terminator v3.1 cycle sequencing kit (Applied Biosystem, UK) was used as recommended by the manufacturer's protocol.

Sequences alignment (224 bp fragments of VP1) and construction of phylogenetic tree (Neighbor-joining) to detect the genetic relatedness of the tested strain of the current study compared to other strains worldwide registered in gene bank were carried out using BioEdite software program V.5.0.9 (Goris et al., 2007) and MEGA-7 software program (Kumar et al., 2016).

\section{Histopathological examination}

Heart specimens from dead calves were taken and fixed in $10 \%$ buffered formalin followed by histopathological examination 18. Slaoui M., Fiette L. Histopathology procedures: from tissue sampling to histopathological evaluation (Slaoui and Fiette, 2011).

\section{Statistical analysis}

The obtained results from the experiments were expressed as mean \pm SEM and were analyzed using (SPSS Statistics for Windows, version 23.0. Armonk, NY: IBM Corp). Differences were declared significant when $(\mathrm{P}<0.05)$.

\section{RESULTS}

\section{ECG and biochemical findings}

ECG of FMD infected buffalo calves showed bradycardia with ventricular premature depolarization which characterized by prolongation of T-wave with flattening of $\mathrm{P}$ - wave and significant $(\mathrm{P}<0.01)$ increased $\mathrm{QRS}$ duration with significant $(\mathrm{P}<0.01)$ decrease in its amplitude compared with healthy calves. There was significant $\left(\mathrm{P}<0.0^{\circ}\right)$ decrease in PR and RT intervals while there was significant $(\mathrm{P}<0.05)$ increase in $\mathrm{ST}$ and $\mathrm{QT}$ intervals in FMD diseased calves than that of healthy ones (Fig. 1 and table 1). There were significant $(\mathrm{P}<0.01)$ increases in $(\mathrm{cTnI}),(\mathrm{CK}-\mathrm{MB})$, urea, $\mathrm{CL}$ and $\mathrm{K}$, while there was significant $(\mathrm{P}<$ $0.01)$ decrease in Na levels in FMD infected calves than that of healthy ones (Table 2).

Serological detection of FMD antibodies and serotyping using ELISA.

The percentage of non-structural protein of serotype O was $31.5 \%$ (63 out of 200) which reflected infection by FMD serotype O. Moreover, $51.5 \%$ of the samples (103 out of 200) showed detection of structural protein that been created by the body immune system as a result of vaccination. Furthermore, these structural proteins were against some FMD serotypes not for all serotypes. Serotype $\mathrm{O}$ was the predominant as shown in Table 3. On the other hand, there were no protective antibodies against FMDV in $17 \%$ of the examined samples (34 out of the 200) which indicated vaccination failure in this case.

Virus sequencing and phylogenetic analysis RT-PCR successfully amplified the target gene (VP1) from all tissue samples. After direct sequencing of the $283 \mathrm{bp} \mathrm{PCR}$ products, analysis was carried out on 224-nucleotide sequences corresponding to part of the FMDVP1 encoding gene [from nucleotides 3707 to 3932 of the full length FMDV genome. Depending on the nucleotide homology between the identified strains after alignment, the results revealed presence of 5 different strains (strain 1 to strain 5) and all belongs to $\mathrm{O}$ strain of FMD (Fig. 2).

By comparing the sequences data of the five different identified stains in this study with vaccinal strain (Manisa/Turkey) and others Egyptian strains (Dakahlia/ 2014, Ismaalia/ 2013, El-Minia/ 2013 and Alexandria 2013) from the GeneBank using their 
accession numbers, it was found that there were 2 types of mutations occurred by nucleotide substitution (point mutation) and by deletion in the identified strains meaning that the identified strains were unique and different from the vaccinal and others Egyptian strains (Fig. 3). The results of phylogenetic analysis indicated that the identified strains in this study were clustered with topotype ME-SA (Fig.3).

\section{Histopathological findings}

Histopathological examination of the heart of dead calves revealed severe interstitial myocarditis with heavy inflammatory cellular infiltration consisting of lymphocytes, macrophage and plasma cell (Fig. 4a). Zenker's necrosis of the myocardial muscle with massive leukocytic cellular infiltrates accompanied by distortion and dissolution of the myocardial parenchyma was also observed (Fig. 4b).

B

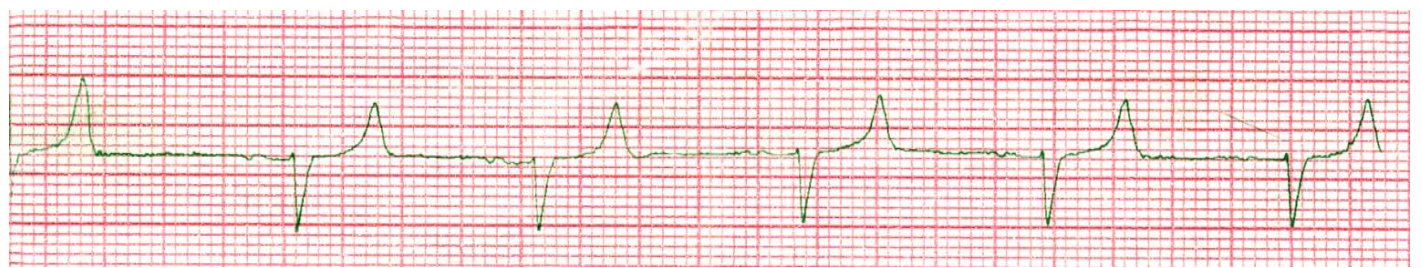

A

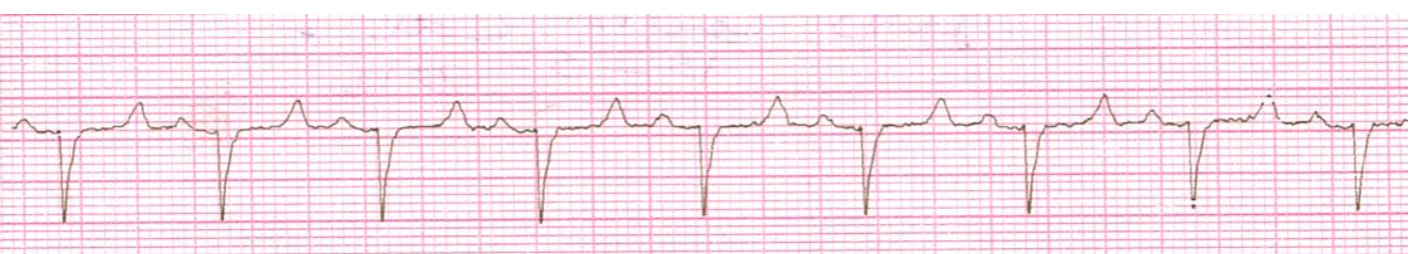

Fig. (1): ECG of FMD infected buffalo calf (B) showing bradycardia with ventricular premature depolarization which characterized by prolongation of T-wave with flattening of $\mathrm{P}$ - wave and increased QRS duration with decrease in its amplitude compared with healthy calves (A).

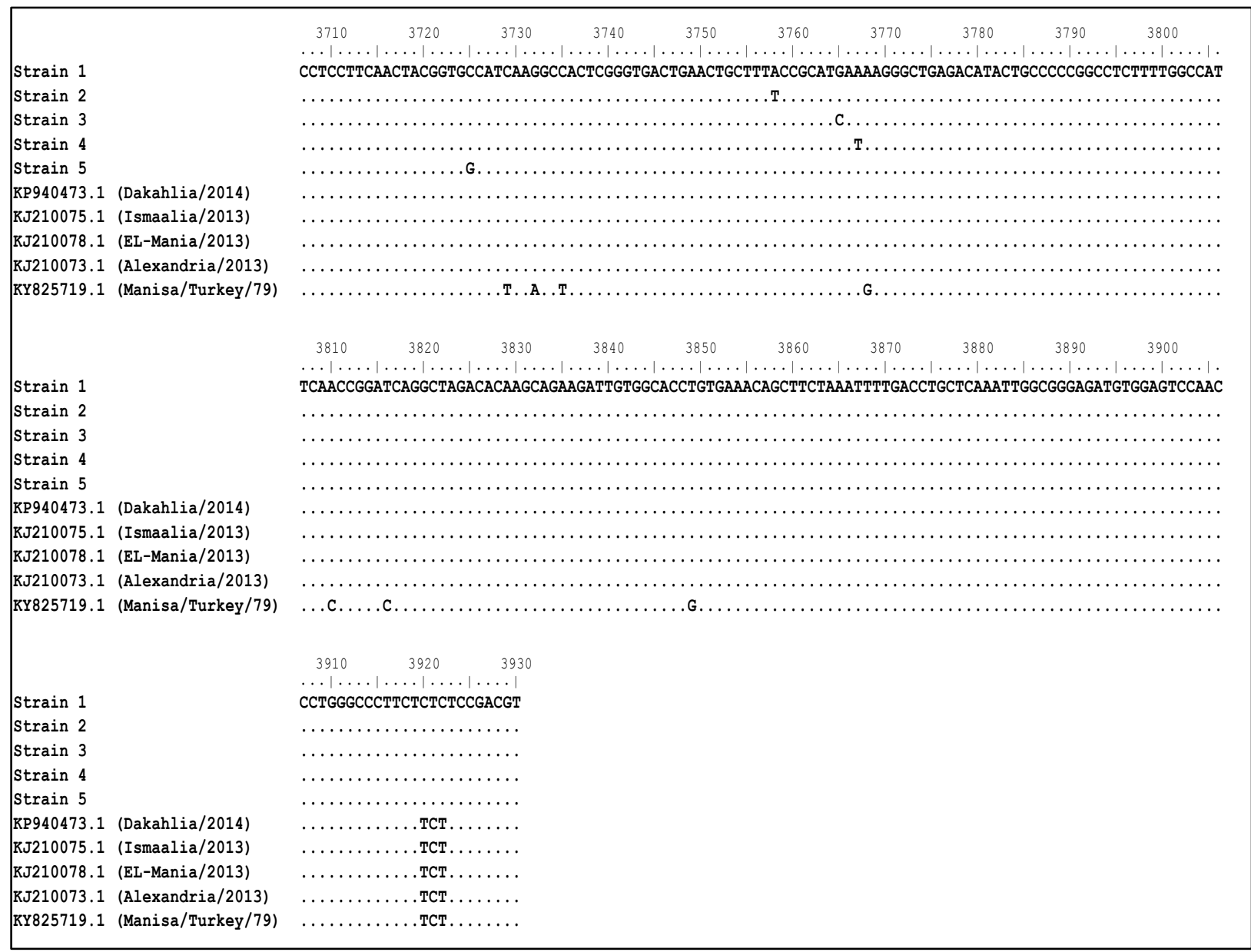

Fig. (2): Sequences data of the five different detected stains in this study with vaccinal strain (Manisa/Turkey) and others Egyptian strains (Dakahlia/ 2014, Ismaalia/ 2013, El-Minia/ 2013 and Alexandria 2013). Mutation by substitution and by deletion were found. 


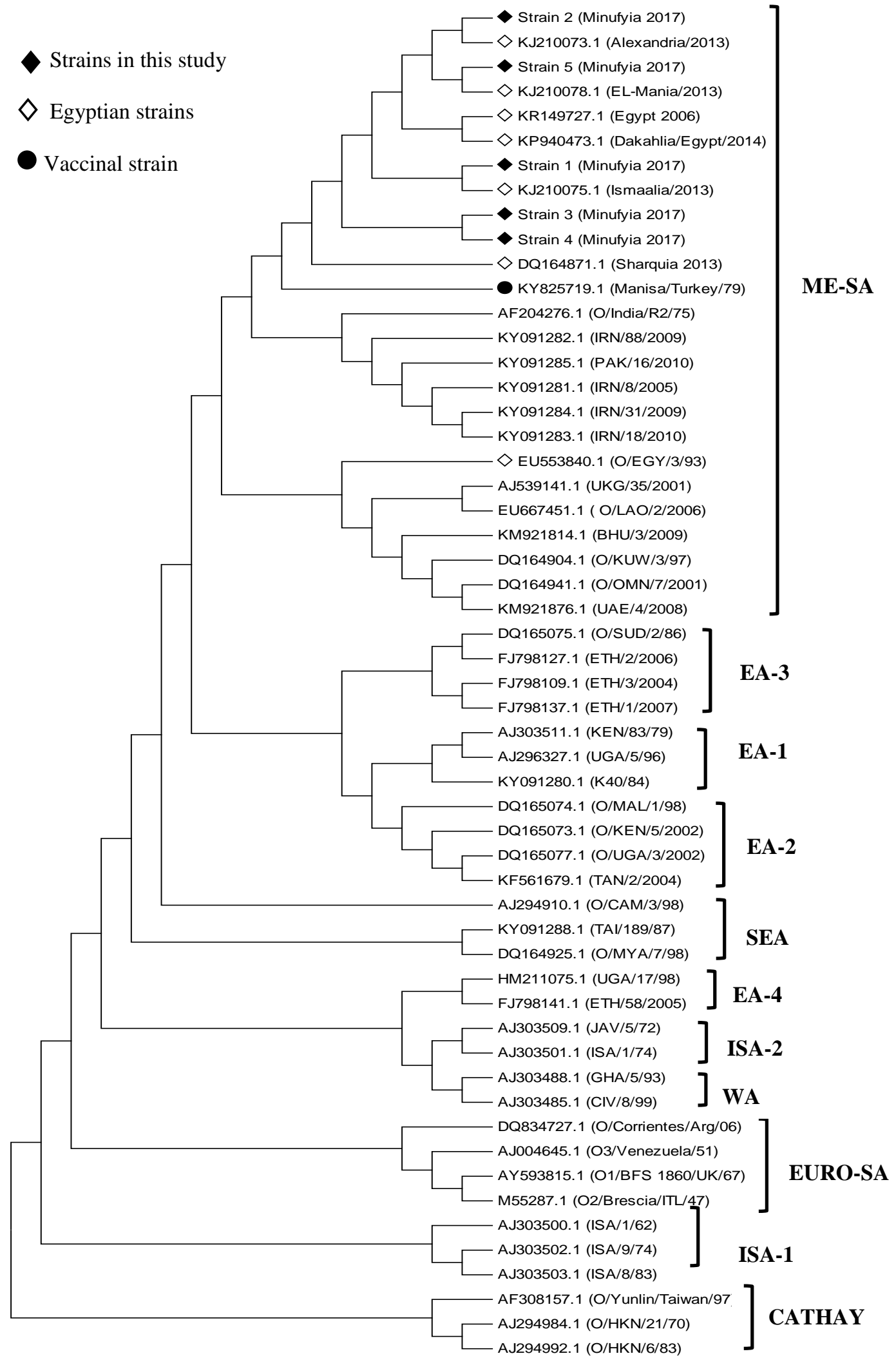

Fig. 3: Phylogenetic analysis of the FMD strains. The phylogenetic tree was based on partial sequences (224 nt). The evolutionary history was inferred using the Neigbor-joining method with bootstrap probability more than 70 $\%$. The detected strains were clustered with topotype ME-SA. 

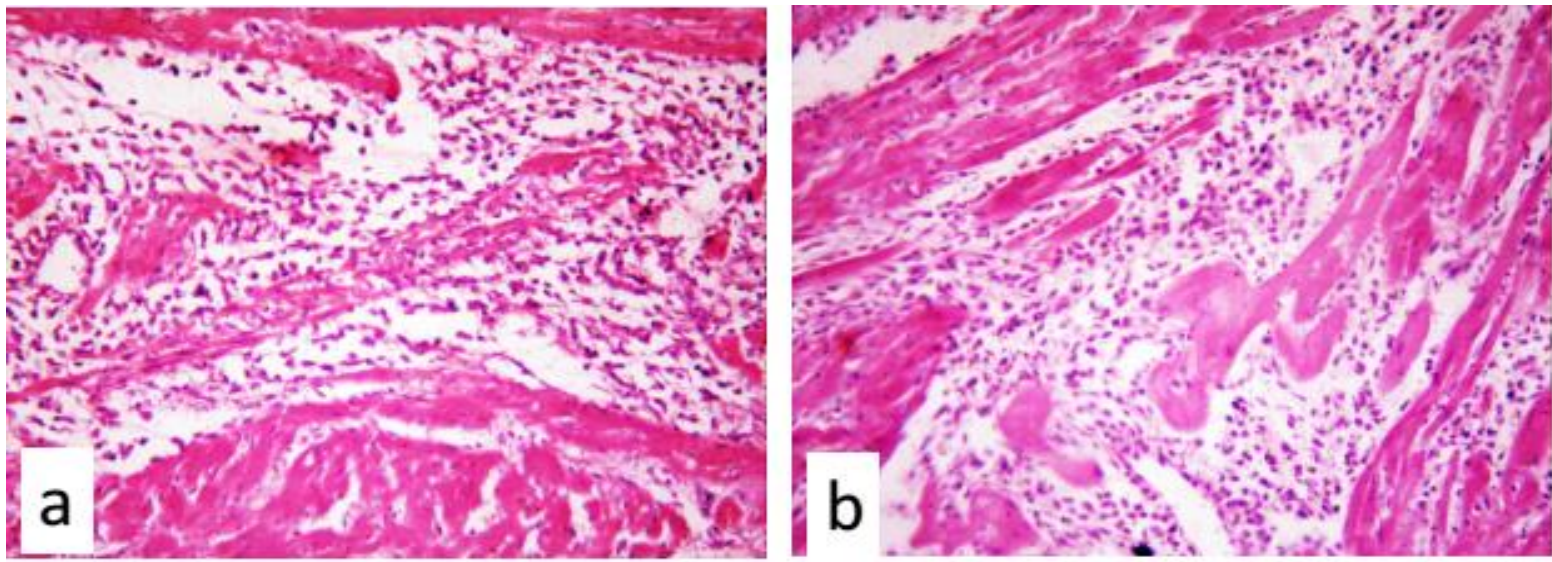

Fig. 4a: Heart of dead calf showing severe interstitial myocarditis with heavy inflammatory cellular infiltration consisting of lymphocytes, macrophage and plasma cell. (H\&E x200).

Fig. 4b: Heart of dead calf showing zenker's necrosis of the myocardial muscle with massive leukocytic cellular infiltrates accompanied by distortion and dissolution of the myocardial parenchyma. (H\&E x200).

Table 1: ECG traces in healthy and FMD infected Egyptian buffalo calves.

\begin{tabular}{|c|c|c|c|c|c|c|c|c|c|c|}
\hline \multirow{2}{*}{ Animal - } & \multicolumn{2}{|c|}{$\mathrm{P}$-wave } & \multicolumn{2}{|c|}{ QRS complex } & \multicolumn{2}{|c|}{ T-Waves } & \multirow{2}{*}{$\begin{array}{c}\text { PR- } \\
\text { Interval }\end{array}$} & \multirow{2}{*}{$\begin{array}{c}\text { RT- } \\
\text { Interval }\end{array}$} & \multirow{2}{*}{$\begin{array}{c}\text { ST - } \\
\text { Interval }\end{array}$} & \multirow{2}{*}{$\begin{array}{c}\text { QT - } \\
\text { Interval }\end{array}$} \\
\hline & Amplitude & Duration & Amplitude & Duration & Amplitude & Duration & & & & \\
\hline $\begin{array}{l}\text { Healthy } \\
\text { calves }\end{array}$ & $\begin{array}{c}0.19 \pm \\
0.01\end{array}$ & $\begin{array}{c}0.08 \pm \\
0.04\end{array}$ & $\begin{array}{c}0.86 \pm \\
0.04\end{array}$ & $\begin{array}{c}0.04 \pm \\
0.01\end{array}$ & $\begin{array}{c}0.41 \pm \\
0.01\end{array}$ & $\begin{array}{c}0.08 \pm \\
0.01\end{array}$ & $\begin{array}{c}0.21 \pm \\
0.01\end{array}$ & $\begin{array}{c}0.24 \pm \\
0.02\end{array}$ & $\begin{array}{c}0.16 \pm \\
0.02\end{array}$ & $\begin{array}{c}0.28 \\
\pm 0.01\end{array}$ \\
\hline $\begin{array}{l}\text { FMD } \\
\text { infected } \\
\text { calves }\end{array}$ & $\begin{array}{l}0.06 \pm \\
0.01 * *\end{array}$ & $\begin{array}{l}0.28 \pm \\
0.17 * *\end{array}$ & $\begin{array}{l}0.77 \pm \\
0.01 *\end{array}$ & $\begin{array}{l}0.07 \pm \\
0.01 *\end{array}$ & $\begin{array}{l}0.65 \pm \\
0.03 * *\end{array}$ & $\begin{array}{l}0.17 \pm \\
0.01 * *\end{array}$ & $\begin{array}{l}0.17 \pm \\
0.01 *\end{array}$ & $\begin{array}{l}0.20 \pm \\
0.01 *\end{array}$ & $\begin{array}{l}0.21 \pm \\
0.01 *\end{array}$ & $\begin{array}{c}0.34 \pm \\
0.02 *\end{array}$ \\
\hline
\end{tabular}

Means $( \pm \mathrm{SE})$ are significantly different when $(\mathrm{P}<0.05)^{*}$ and $(\mathrm{P}<0.01)^{* *}$.

Table 2: Biochemical parameters in healthy and FMD infected Egyptian buffalo calves.

\begin{tabular}{lllcccc}
\hline & $\mathrm{cTnI}(\mathrm{U} / \mathrm{L})$ & $\mathrm{CK}-\mathrm{MB}(\mathrm{U} / \mathrm{L})$ & $\mathrm{Na}(\mathrm{mEq} / \mathrm{L})$ & $\mathrm{K}(\mathrm{mEqL})$ & $\mathrm{Cl}(\mathrm{mEq} / \mathrm{L})$ & $\mathrm{Urea}(\mathrm{mg} / \mathrm{dl})$ \\
\hline Diseased & $8.1 \pm 0.6^{* *}$ & $4.35 \pm 0.18^{* *}$ & $129.13 \pm 2.40^{* *}$ & $4.74 \pm 0.10^{* *}$ & $144.26 \pm 2.51^{* *}$ & $41.77 \pm 0.99 * *$ \\
\hline Control & $0.8 \pm 0.4$ & $2.53 \pm 0.2$ & $145.14 \pm 1.30$ & $3.52 \pm 0.31$ & $112.63 \pm 2.32$ & $25.42 \pm 1.17$ \\
\hline
\end{tabular}

Means $( \pm \mathrm{SE})$ are significantly different when $(\mathrm{P}<0.01)^{* * *}$.

Table 3: Serotyping of FMDV antibodies of 200 Egyptian buffalo calves vaccinated with local vaccine (ND=Non-detected)

\begin{tabular}{llll}
\hline Type of antibodies & $\begin{array}{l}\text { No. of } \\
\text { samples }\end{array}$ & $\%$ & $\begin{array}{l}\text { Serotyping of } \\
\text { FMD } \\
\text { Antibodies }\end{array}$ \\
\hline $\begin{array}{l}\text { Against natural infection } \\
\text { (Non- structural proteins) }\end{array}$ & 63 & $31.5 \%$ & $\mathrm{O}$ \\
\hline $\begin{array}{l}\text { Against trivalent vaccine } \\
\text { (Structural proteins) }\end{array}$ & 40 & $20 \%$ & $\mathrm{O}, \mathrm{A}$ \\
\cline { 2 - 4 } & 43 & $21.5 \%$ & $\mathrm{O}, \mathrm{SAT} 2$ \\
\hline ND & 20 & $10 \%$ & $\mathrm{O}$ \\
\hline
\end{tabular}




\section{DISCUSSION}

FMD is considered one of the important infectious contagious viral diseases affecting cloven hoofed animals producing a drastic economic loses (KnightJones and Rushton 2013). In Egypt, FMD has taken an enzootic form and many outbreaks had occurred since 1950 and onwards. FMDV type $\mathrm{O}$ was the most prevalent until serotype A appeared in 2006 and serotype SAT2 in 2012, however, the serotype $\mathrm{O}$ still the most predominant serotype until now (Ahmed et al., 2012; Knowles et al., 2007). Vaccination of cattle and other susceptible species against FMD considered the only way for controlling the disease in Egypt, moreover, the identification of the causal agent and its serotype was imperative for choosing and formulating an effective vaccine (Ghanem and Abdel-Hamid 2010). Another method for controlling the disease is determination of its topology and understanding its epidemiology using molecular diagnostic technique through analysis of VP1 sequence then phylogenetic analysis thereby, tracking its transmission and sources (DiMarchi et al., 1986; Knowles et al., 2007). In September 2016, there was a new destructive FMD outbreak that struck a critical income source of the rural community in Egypt.

ECG is the clinical method of choice to evaluate cardiac problems associated with the production and conduction of electrical stimuli. It is also a useful tool in evaluating electrolyte disturbances. Ventricular premature beats characterized by abnormal amplitude and duration of ORS complexes and $\mathrm{T}$ waves are indicative of myocardial diseases (Mohammad et al., 2013; Radostits OM et al., 2007). FMD associated with excessive salivation resulting in acidosis which characterized by low level of arterial $\mathrm{pH}$ and reduced plasma bicarbonate concentration following the loss of bicarbonate in saliva. Extracellular and intracellular buffering and respiratory compensations minimize the change in blood $\mathrm{pH}$ until the kidney can excrete sufficient amount of hydrogen ion to correct the acid-base imbalance. Acidosis causing movement of potassium ion out the cell into the extracellular space and enhances the movement of hydrogen ion into the cell resulting in hyperkalemia (Hall 2001) which characterized clinically by cardiac arrhythmia and this agree with the obtained electrocardiographic results of this study. Our results also revealed hyponatremia, and hyperkalemia which were similar to those results obtained by Gattani et al. (2011). On the same hand, the decrease in chloride could be achieved by hyper salivation which facilitates sodium and chloride loss (Gattani et al., 2011; Mahmoud and Neamat-Allah 2016) and changes in pancreatic $\beta$-cell function which occurred during the clinical course of FMD as reported by Shawky et al.
(2013). Significant increase in (cTnI) and (CK-MB) which are considered as cardiac biomarker in large animals, providing a sensitive and persistent indicator of myocardial injury (Radostits OM et al., 2007). It has been reported that serum (cTnI) concentration is an earlier marker of myocardial damage after virus infection (Lim et al., 2005). Histopathological findings were included myocardial degeneration, necrosis, infiltrations of muscle fiber with mononuclear cells especially lymphocytes and few plasma cells (Aktas et al., 2015) which may indicate to myocarditis (Aslani $e t$ al., 2013; Kaya et al., 2013).

The incidence of non-structural protein serotyping $\mathrm{O}$ of FMDV was $31.5 \%$ in serum samples collected from vaccinated buffalo calves. The vaccine should induce the immune system to produce the protective antibodies against all serotypes of FMD virus (Hegde et al., 2016). $17 \%$ of vaccinated buffalo calves had not any protective antibodies against FMD virus. This means that these buffalo calves are more susceptible for any serotype of FMD virus infection. While, the $51.5 \%$ have some serotype of FMD virus antibodies this means that not all vaccinated buffalo calves have the three serotypes of antibodies against FMD virus, although the local vaccine should provide the animal with protective antibodies against $\mathrm{O}, \mathrm{A}$ and SAT2 serotype of FMD virus. The results of the current study indicated that the local vaccine did not promote the immune system and is not enough to control against FMD virus.

The results of molecular detection of the virus using RT-PCR indicated that the detected serotype in this outbreak was $\mathrm{O}$ that is the most predominant (Ahmed et al., 2012). While the sequencing of the detected strain targetting the VP1 protein showed that there were two types of mutation occurred by nucleotide substitution (point mutation) and by deletion in the detected strains (Bergmann et al., 2003; Ding et al., 2013) when compared with the vaccinal and others Egyptian strains. These kinds of mutations cause change in a sequence which subsequently can cause a change in primary, secondary and even tertiary protein structural, so this change in a sequence may be strongly related to antibody escape policy of FMD from host immune mechanism and appearance of outbreaks of FMD even in vaccinated animals (Domingo et al., 2002).

Neighbor-joining tree analysis of the detected strains in this study when aligned and compared with Egyptian strains and 11 topotypes of the FMD serotype $\mathrm{O}$ and their lineages spread in the globe was carried out and the results demonstrated that the detected strains were clustered with topotype Middle East-South Asia (ME-SA) (Barker et al., 1993). 
Vaccination constitutes an important control policy for FMD in affected areas with advanced eradication programs, as well as in free regions that decide to use immunization as a control measure after a recent introduction of the disease (Beck and Strohmaier 1987). In Egypt, the local commercial (trivalent O, A and SAT2) inactivated vaccines were used for rapid control of the disease that supplied by the FMD Department, Veterinary Serum and Vaccine Research Institute, Abassia, Cairo (Domingo et al., 2002; Soltan et al., 2017).

According to the results of the current study, we can conclude that the identified strains in FMD infected Egyptian buffalo calves were unique and different from the vaccinal and other Egyptian strains as well as they were clustered with Topotype ME-SA Panasian viruses. Cardiac biomarkers as serum (cTnI) and (CK-MB) along with ECG can be used as useful prognostic tools in FMD infected Egyptian buffalo calves.

\section{Conflict of interest}

Authors declare no conflict of interest.

\section{REFERENCES}

Ahmed, H.; Salem, S.; Habashi, A.; Arafa, A.; Aggour, M.; Salem, G.; Gaber, A.; Selem, O.; Abdelkader, S. and Knowles, N. (2012): "Emergence of Foot-and-Mouth Disease Virus SAT 2 in Egypt During 2012." Transbound. Emerg. Dis., 59, 476-481.

Aktas, M.S.; Ozkanlar, Y.; Oruc, E.; Sozdutmaz, I. and Kirbas, A. (2015): "Myocarditis associated with foot-and-mouth disease in suckling calves." Vet. Arhiv, 85, 273-282.

Arzt, J.; Baxt, B.; Grubman, M.; Jackson, T.; Juleff, N.; Rhyan, J.; Rieder, E.; Waters, R. and Rodriguez, L. (2011): "The Pathogenesis of Foot-and-Mouth Disease II: Viral Pathways in Swine, Small Ruminants, and Wildlife; Myotropism, Chronic Syndromes, and Molecular Virus-Host Interactions." Transboundary and emerging diseases, 58(4), 305-326.

Aslani, M.R.; Mohri, M. and Movassaghi, A.R. (2013): "Serum troponin I as an indicator of myocarditis in lambs affected with foot and mouth disease." Vet Res Forum, 4(1), 59-62.

Barker, I.K.; Van Dreumel, A.A. and Palmer, N. (1993): The alimentary system. In: Pathology of Domestic Animals, 4th ed. (Jubb, K. V. F., P. C. Kennedy, N. Palmer, Eds.). Academic Press, San Diego, CA. pp.141-144.

Beck, E. and Strohmaier, K. (1987): "Subtyping of European foot-and-mouth disease virus strains by nucleotide sequence determination." J. Virol., 61(5), 1621-1629.

Bergmann, I.E.; Malirat, V.; Neitzert, E. and Melo, E.C. (2003): "Vaccines and companion diagnostic tests for foot-and-mouth disease virus. An overview of the experience in South America." Develop. Biol., 114, 59-66.

Carrillo, C.; Tulman, E.; Delhon, G.; Lu, Z.; Carreno, A.; Vagnozzi, A.; Kutish, G. and Rock, D. (2005): "Comparative genomics of foot-and-mouth disease virus." J. Virol., 79(10), 6487-6504.

Cottam, E.M.; Thébaud, G.; Wadsworth, J.; Gloster, J.; Mansley, L.; Paton, D.J.; King, D.P. and Haydon, D.T. (2008): "Integrating genetic and epidemiological data to determine transmission pathways of foot-and-mouth disease virus." Proceedings of the Royal Society of London B: Biol. Sci., 275(1637), 887-895.

DiMarchi, R.; Brooke, G.; Gale, C.; Cracknell, V.; Doel, T. and Mowat, N. (1986): "Protection of cattle against foot-and-mouth disease by a synthetic peptide." Sci., 232(4750), 639-641.

Ding, Y.Z.; Chen, H.T.; Zhang, J.; Zhou, J.H.; Ma, L.N.; Zhang, L.; Gu, Y. and Liu, Y.S. (2013): "An overview of control strategy and diagnostic technology for foot-and-mouth disease in China." Virol J, 10, 78.

Domingo, E.; Baranowski, E.; Escarmis, C. and Sobrino, F. (2002): "Foot-and-mouth disease virus." Comparative immunology, microbiology and infectious diseases, 25(5), 297-308.

El-Bagoury, G.F.; Helmy, N.M.; El-Habbaa, A.S. and El-Habashy, R.A. (2017): "Convenience of rapid detection tests in suspecting prevalence of FMD virus in Egypt between 2016-2017." BVMJ, 33, 476-488.

El-Bagoury, G.F.; Sharawi, S.S.; El-Nahas, E.M.; Darwish, D.M. and Saad, M.A. (2015): "Antigenic relatedness of FMD serotypes $\mathrm{O}$ and A local Egyptian isolate with vaccinal strains in the local commercial and imported vaccines." B.V.M.J., 28(1), 235-240.

Gattani, A.; Gupta, K.; Koshal, J.G. and Gupta, R.S. (2011): " Metabolic profile of foot and mouth disease stressed sheep in semi Arid region ." J. St. Physio. Bioch., 7(148-153).

Ghanem, M.M. and Abdel-Hamid, O.M. (2010): "Clinical, haematological and biochemical alterations in heat intolerance (panting) syndrome in Egyptian cattle following natural foot-and-mouth disease (FMD)." Trop. Anim. Health. Prod., 42(6), 1167-73.

Goris, N.; Merkelbach-Peters, P.; Diev, V.; Verloo, D.; Zakharov, V.; Kraft, H.-P. and De Clercq, K. (2007): "European Pharmacopoeia foot-and-mouth disease vaccine potency testing in cattle: between test variability and its consequences." Vaccine 25, 3373-3379. 
Hall, T. (2001): "BioEdit v5. 0.9." North Carolina State University, Raleigh, NC.

Hegde, R.; Kowalli, S.; Nagaraja, K.; Dharanesha, N.K.; Seema, C.M.; Khan, T.A.; Nagaraj, G.V.; Srikala, K.; Sudharshana, K.J.; Nagaraju, D.; Rao, S.; Giridhara, P. and Byregowda, S.M. (2016): "Serosurveillance of foot and mouth disease in Karnataka state, India: a 3 years study." Vir. Dis., 27(3), 294302.

Henry, R.F.; Cannon, D.C. and Winkelman, J.W. (1974): "Clinical chemistry principles and techniques. 2 nd. Ed. Herper and Reo, Hagerstown MD.".

Hiwing, R.W. (1977): "Cardiac arrhythmia in the horse." J. Amer. Vet. med. Assoc., 170(2), 153-163.

Jaffe, A.S.; Landt, Y.; Parvin, C.A.; Abendschein, D.R.; Geltman, E.M. and Ladenson, J.H. (1996): "Comparative sensitivity of cardiac troponin I and lactate dehydrogenase isoenzymes for diagnosing acute myocardial infarction." Clin Chem, 42(11), 1770-6.

Kaplan, L.A. and Pesca, A.J. (1996): "Clinical chemistry. 1 st. Ed. Mosby Company, Toronto.".

Kaya, A.; Kozat, S.; Ozkan, C.; Yildirim, S.; Akgul, $Y$. and Akgul, O. (2013): "Serum homocy steine levels in calves with foot and mouth disease. 12, ." JAVA, 12, 1357-1361.

Knight-Jones, T. and Rushton, J. (2013): "The economic impacts of foot and mouth diseaseWhat are they, how big are they and where do they occur?" Prev. Vet. Med., 112, 161173.

Knowles, N.; Nazem Shirazi, M.; Wadsworth, J.; Swabey, K.; Stirling, J.; Statham, R.; Li, Y.; Hutchings, G.; Ferris, N. and Parlak, $\ddot{U}$. (2009): "Recent spread of a new strain (AIran-05) of foot-and-mouth disease virus type A in the Middle East." Transboundary and emerging diseases, 56(5), 157-169.

Knowles, N.; Wadsworth, J.; Bachanek-Bankowska, $K$. and King, D. (2016): "VP1 sequencing protocol for foot and mouth disease virus molecular epidemiology." Rev Sci Tech 35, 741-755.

Knowles, N.J.; Wadsworth, J.; Reid, S.M.; Swabey, K.G.; El-Kholy, A.A.; El-Rahman, A.O.A.; Soliman, H.M.; Ebert, K.; Ferris, N.P. and Hutchings, G.H. (2007): "Foot-and-mouth disease virus serotype A in Egypt." Emerging infectious diseases, 13(10), 1593.

Kumar, S.; Stecher, G. and Tamura, K. (2016): "MEGA7: molecular evolutionary genetics analysis version 7.0 for bigger datasets." Molecular biology and evolution, 33(7), 1870-1874.

Laila, E. and Daoud, A. (2004): "Detection and significance of FMD-3ABC antibodies assessed under experimental conditions." $J$. Egy. Vet. Med. Assoc., 64(3), 71-81.

Li, P.; Lu, Z.; Bao, H.; Li, D.; King, D.P.; Sun, P.; Bai, X.; Cao, W.; Gubbins, S.; Chen, Y.; Xie, B.; Guo, J.; Yin, H. and Liu, Z. (2011): "Invitro and in-vivo phenotype of type Asia 1 foot-and-mouth disease viruses utilizing two non-RGD receptor recognition sites." $B M C$ Microbiol., 11, 154-154.

Lim, B.K.; Shin, J.O.; Choe, S.C.; Choi, S.W.; Jeong, J.O.; Seong, I.W.; Kim, D.K. and Jeon, E.S. (2005): "Myocardial injury occurs earlier than myocardial inflammation in acute experimental viral myocarditis." Exp. Mol. Med., 37(1), 51-7.

Longjam, N.; Deb, R.; Sarmah, A.; Tayo, T.; Awachat, V. and Saxena, V. (2011): "A brief review on diagnosis of foot-and-mouth disease of livestock: conventional to molecular tools." Vet. Med. Inter., 2011.

Mahmoud, E.A. and Neamat-Allah, A.N.F. (2016): "Hemato-Biochemical Studies on Egyptian Buffaloes and Calves Naturally Infected with Foot and Mouth Disease Virus Serotype SAT2." Bulletin UASVM Vet. Med., 73(2), 230-237.

Mandour, M.F.; Mohamed, M.A.-E.; Shahira, A.M.A.; Abu El-Naga, H.I.E.-S.; Azab., M.S. and El-Tarabili, M.M. (2014): "Rapid Detection of Foot and Mouth Disease Virus from Tongue Epithelium of Cattle and Buffaloes in Suez Canal Area, Egypt from 2009-2011." Int. J. Virol., 10(1), 55-62.

Mohammad, R.A.; Mehrdad, M. and Ahmad, R.M. (2013): "Serum troponin I as an indicator of myocarditis in lambs affected with foot and mouth disease." Vet. Res. Foru., 4(1), 59-62.

OIE. (2009): "OIE Terrestrial Manual, Foot and mouth disease.", Chapter 2.1.5.

Patton, C.J. and Crouch, S.R. (1977): "Enzymetic determination of urea." Anal. Chem., 49, 464469.

Racaniello, V.R. (2001): "The Viruses and Thier Replocation." Fiel. Virol., 1, 685-722.

Radostits, OM.; Gay, CC. and Hinchcliff, KW.e.a. (2007): "Veterinary Medicine - A textbook of the diseases of cattle, horses, sheep, pigs and goats. 10th ed. London, UK: WB Saunders 2007; 1223-1230.".

Shawky, M.; Abd El-Aty, M.; Fakry, H.M.; Daoud, H.M.; El-Sayed, E.I.; Mossad, W.G.; Rizk, S.A.; Abu-Elnaga, H.; Mohamed, A.A.; Abd El-Kreem, A. and Farouk, E.M. (2013): "Isolation and Molecular characterization of foot and mouth disease SAT2 Virus during outbreak 2012 in Egypt." J. Vet. Adv., 3, 6068.

Slaoui, M. and Fiette, L. (2011): " Histopathology procedures: from tissue sampling to histopathological evaluation." Methods $\mathrm{Mol}$ Biol, 691, 69-82. 
Soltan, M.A.; Negmaldin, A.H.; El-Diasty, M.M.; Mansour, S.M.G.; Elbadry, M.A. and Wilkes, R.P. (2017): "Molecular characterization of circulating Foot and mouth disease virus (FMDV) serotype O topotype EA-3 and serotype A (African topotype) genotype IV in Egypt, 2016." Vet. Microbiol., 208, 89-93.
Weber, M.; Rau, M.; Madlener, K.; Elsaesser, A.; Bankovic, D.; Mitrovic, V. and Hamm, C. (2005): "Diagnostic utility of new immunoassays for the cardiac markers cTnI, myoglobin and CK-MB mass." Clin. Biochem., 38(11), 1027-30.

\title{
دراسه جزيئيه علي عجول الجاموس المصريه المصابه بالحمي القلاعيه ومرجعية رسام القلب الكهربائي والدلالات الحيويه القلبيه كاداوات النديه الهار
}

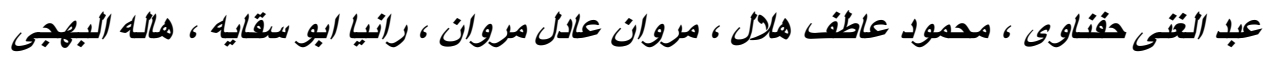

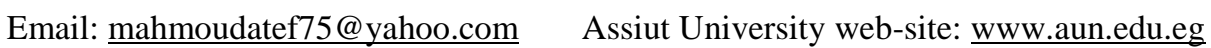

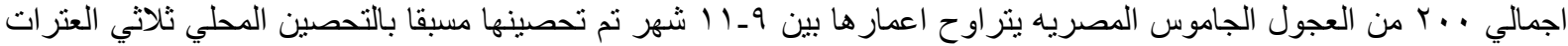

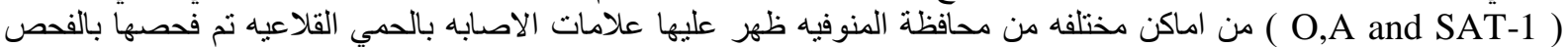

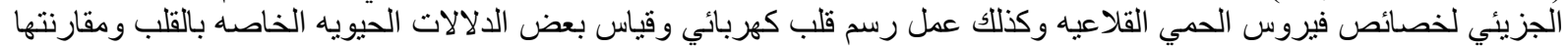

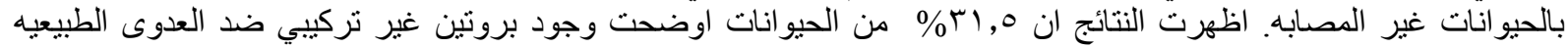

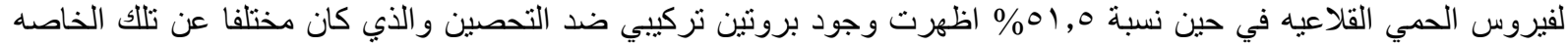

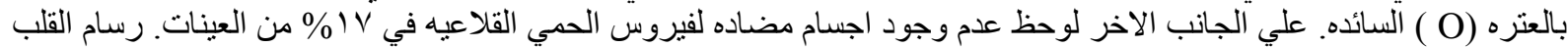

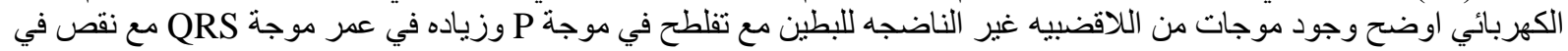

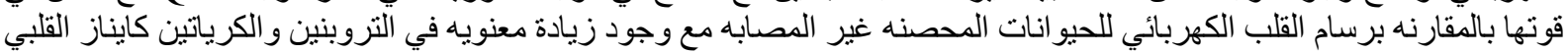

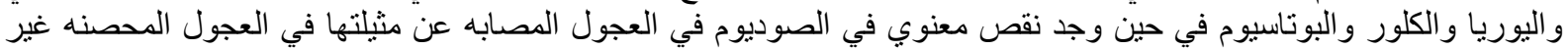

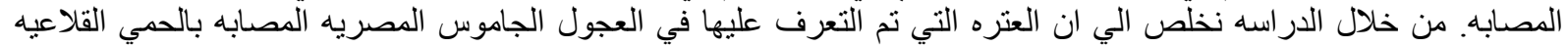

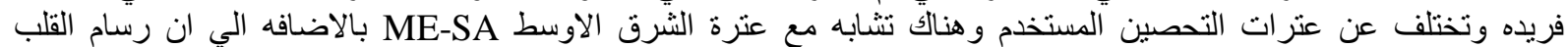
الكهربائي ودلالات القلب قد تكون اداه تعريفيه بمأل مرض الحمي القاك القلاعيه في العجول الجاموس المصريه
\end{abstract}

